\title{
Article/Artigo
}

\section{Molecular characterization of Salmonella strains in individuals with acute diarrhea syndrome in the State of Sucre, Venezuela}

\author{
Caracterização molecular de cepas de Salmonella em indivíduos com síndrome da diarreia \\ aguda no Estado de Sucre, Venezuela
}

Hectorina Rodulfo ${ }^{1}$, Marcos De Donato ${ }^{1}$, Jesús Luiggi ${ }^{1}$, Elvia Michelli ${ }^{2}$, Adriana Millán ${ }^{1}$ and Miriam Michelli ${ }^{1}$ \begin{abstract}
Introduction: In Venezuela, acute diarrheic syndrome (ADS) is a primary cause of morbimortality, often involving the Salmonella genus. Salmonella infections are associated with acute gastroenteritis, one of the most common alimentary intoxications, and caused by the consumption of contaminated water and food, especially meat. Methods: Conventional and molecular methods were used to detect Salmonella strains from 330 fecal samples from individuals of different ages and both sexes with ADS. Polymerase chain reaction (PCR) was used for the molecular characterization of Salmonella, using invA, sefA, and fli $\mathrm{C}$ genes for the identification of this genus and the serotypes Enteritidis and Typhimurium, respectively. Results: The highest frequency of individuals with $\mathrm{ADS}$ was found in children 0-2 years old (39.4\%), and the overall frequency of positive coprocultures was $76.9 \%$. A total of $14(4.2 \%)$ strains were biochemically and immunologically identified as Salmonella enterica subsp. enterica, of which 7 were classified as belonging to the Enteritidis serotype, 4 to the Typhimurium serotype, and 3 to other serotypes. The $S$. enterica strains were distributed more frequently in the age groups 3-4 and 9-10 years old. Conclusions: The molecular characterization method used proved to be highly specific for the typing of $S$. enterica strains using DNA extracted from both the isolated colonies and selective enrichment broths directly inoculated with fecal samples, thus representing a complementary tool for the detection and identification of ADS-causing bacteria.
\end{abstract}

Keywords: Molecular diagnosis. Coproculture. Acute diarrhea. Polymerase chain reaction. Salmonella.

\section{RESUMO}

Introdução: Na Venezuela, síndrome da diarreia aguda (SDA) é a principal causa de mórbimortalidade, muitas vezes envolvem o gênero Salmonella. Infecções por Salmonella são associadas com gastroenterite aguda, uma das mais comuns intoxicações alimentares causada pelo consumo de água e alimentos contaminados, principalmente carne. Métodos: Métodos convencionais e moleculares foram usados para detectar cepas de Salmonella em 330 amostras de fezes de indivíduos com SDA de diferentes idades e ambos os sexos. A reação em cadeia da polimerase (PCR) foi utilizada para a caracterização molecular de genes Salmonella invA, sefA e fliC para identificar o gênero e os sorotipos Enteritidis e Typhimurium, respectivamente. Resultados: A maior frequência de indivíduos com SDA foi encontrada em crianças de 0-2 $(39,4 \%)$ anos, e a frequência total de culturas de fezes positiva foi de $76,9 \%$. Um total de 14 (4,2\%) cepas foram bioquímica e imunologicamente identificados como Salmonella enterica subsp. enterica, dos quais 7 foram classificados como pertencentes ao sorotipo Enteritidis, Typhimurium sorotipo 4 e 3 para outros sorotipos. Cepas $S$. enterica foram distribuídas mais frequentemente em grupos de 3-4 e 9-10 anos de idade. Conclusões: O método de caracterização molecular usada provou ser altamente específico para tipificar as estirpes dos S. enterica usando tanto DNA extraído de colônias isoladas e direta e caldos de enriquecimento seletivo inoculados com amostras fecais, o que representa uma ferramenta complementar para a detecção e identificação de bactérias que causam a SDA.

Palavras chaves: Diagnóstico molecular. Coprocultura. Diarreia aguda. Reação em cadeia da polimerase. Salmonella.

1. Laboratório de Genética Molecular, Instituto de Investigaciones en Biomedicina y Ciencias Aplicadas "Dra. Suzan Tai", Universidade de Oriente, Cumaná, Sucre, Venezuela. 2. Laboratorio de Microbiología Clínica, Departamento de Bioanálises, Universidade de Oriente, Cumaná, Sucre, Venezuela.

Address to: Dr. Marcos De Donato. Lab. Genética Molecular/IIBCA/Universidad de Oriente. Av. Universidad 6101 Cumaná, Sucre, Venezuela.

Phone: 58293 417-5285; Fax: 58 293-452-1297

e-mail: marcosdedonato@yahoo.com

Received in 21/05/2011

Accepted in 29/07/2011

\section{INTRODUCTION}

In Venezuela, diarrhea is the ninth cause of death in the population as a whole and the second in children under four years old, with the highest rates reported from the States of Delta Amacuro, Amazonas, and $\mathrm{Zulia}^{1}$. In 2007, a total of $1,724,790$ cases of diarrhea were diagnosed, representing 62.8 cases per 1,000 inhabitants, of which $41.4 \%$ were children under five years old. In 2008, this had increased by $4.4 \%$ to $1,801,214$ cases ( 64.5 cases per 1,000 inhabitants), of which $39.2 \%$ were children under five. In the State of Sucre, a total of 13,707 cases were reported in 2007 and 15,660 in 2008, representing 15.0 and 16.8 cases per 1,000 inhabitants, respectively ${ }^{2}$. The number of cases slightly decreased in 2010 and 2011, with 1,798,792 and $1,624,708$ cases of diarrhea, respectively, registered nationally ${ }^{3}$.

Salmonella infections are associated with acute gastroenteritis, one of the most common alimentary intoxications, caused by the consumption of contaminated water and food, especially meat ${ }^{4-6}$. Salmonella enterica is the species that transmits the disease to humans, its principal reservoirs being animals, particularly reptiles, mammals (mainly cats and dogs), and several birds (chickens, seagulls, pigeons, turkeys, ducks, parrots, and coastal species) $)^{7,8}$.

Urrestarazu et al. ${ }^{9}$ observed that the most important diarrhea-producing enteropathogens in four Venezuelan cities (Mérida, Caracas, Cumaná, and Puerto Ordaz) were: Campylobacter sp. (13\%), Shigella sp. (7\%), and Salmonella sp. (2\%). Similarly, in 2004 the Autonomous Services at the Maracaibo University Hospital, Venezuela, reported Shigella sp. (46.7\%; 167/362), Aeromonas sp. (37.9\%; $137 / 362)$, and Salmonella sp. $(9.4 \% ; 34 / 362)$ as the principal enteropathogens isolated in the pediatric service from January to December $2004^{10}$.

Alternative detection methods that are fast, sensitive, specific, and can be applied on a large scale, are needed for the detection of Salmonella strains. Polymerase chain reaction (PCR) accelerates laboratory diagnosis and, in the case of salmonellosis, 
permits the identification of the exact causal strain ${ }^{11}$. Detection of pathogenic organisms by PCR and Southern hybridization has proven to be more successful than conventional microbiological methods in distinguishing between bacteria species and strains, showing high sensitivity and specificity for the identification of pathogenic bacteria ${ }^{12,13}$.

Due to the high rates of morbidity and mortality in Venezuela produced by acute diarrheic syndrome caused by enteropathogenic bacteria, and the fact that many medical laboratories have been trying to reduce the time needed for the classic bacteriological diagnosis of infections by these bacteria, we aimed to compare the detection of Salmonella strains in fecal samples using bacteriological diagnostic methods and PCR. This is in order to evaluate the use of PCR as an alternative or complementary method that contributes to the diagnosis and specific identification of these pathogens so that the correct antimicrobial treatment can be applied quickly and efficiently, thus reducing the risk for the infected person.

\section{METHODS}

\section{Samples}

A total of 330 fecal samples were collected between April and September 2007 from children and adults of both sexes aged between 0 and 60 years old, but mostly children under 10 years old, who attended the emergency services of the following state clinics in different sectors of the City of Cumaná, State of Sucre, Venezuela: Salvador Allende, Caigüire; Dr. Ramón Martínez, Las Palomas; Laboratorio Comunitario, Villa Olímpica; and La Llanada and Brasil clinics. All of the individuals sampled had acute diarrheic syndrome with evolution times of no more than $72 \mathrm{~h}$ and had not yet received antimicrobial treatment.

\section{Microbiological diagnosis}

Stool samples were collected in sterile plastic cups, with prior instruction given for correct sampling, obtained by spontaneous emission, and given to the investigator. They were inoculated within two hours of emission onto selective and differential media: McConkey (MCK) agar, Salmonella Shigella (SS) agar, and xylose lysine deoxycholate (XLD) agar, using a calibrated inoculating loop in the spread plate method. The media were then incubated in aerobiosis at $35^{\circ} \mathrm{C}$ for 18 to $24 \mathrm{~h}$. Samples were also inoculated into selenite cystine enrichment broth, which favors the development of potentially pathogenic microorganisms and contains substances that inhibit the native flora ${ }^{14}$, and incubated at $35^{\circ} \mathrm{C}$ for 8 to $12 \mathrm{~h}$ before reinoculation onto MCK and SS agars.

Colonies with a presumptive Salmonella morphology as per the phenotypic characteristics in the different culture media were identified biochemically according to the following procedure ${ }^{15}$ : five probable Salmonella colonies were selected from the SS or XLD agars, inoculated into $3.5 \mathrm{~mL}$ brain heart infusion broth (BHI), incubated in aerobiosis at $35^{\circ} \mathrm{C}$ for $10 \mathrm{~min}$, and then inoculated onto the different media. Biochemical tests were then carried out for the determination of glucose and lactose; gas formation and the production of ferrous sulfate from sodium thiosulfate in Kligler agar; the presence of cytochrome oxidase; citrate utilization; urea hydrolysis in Christensen's agar; the presence of phenylalanine deaminase; the liberation of indole; acid production from sugar fermentation; the decarboxylation of lysine, ornithine, and arginine; and the utilization of malonate as the sole carbon source. In addition, a nutrient agar plate was inoculated from each $\mathrm{BHI}$ broth and incubated in aerobiosis at $35^{\circ} \mathrm{C}$ for $24 \mathrm{~h}$; the colonies were used for the oxidase test.

Coprocultures were classified as positive when the samples from individuals with ADS showed abundant bacteria under microscopic examination, and the growth in the culture media was pure (only one type of colony). Bacteria different from Salmonella were then identified to genus or to Escherichia coli using conventional biochemical identification methods ${ }^{14}$.

\section{Molecular characterization}

DNA was extracted from the strains biochemically identified as Salmonella by using the Wizard Genomic DNA Purification Kit (Promega) according to the manufacturer's specifications. In addition, DNA was extracted from samples cultivated in selenite broth by direct inoculation of the fecal sample after incubation for $8 \mathrm{~h}$ at $35^{\circ} \mathrm{C}$. For the identification of Salmonella strains, oligonucleotide pairs that amplify a $457 \mathrm{bp}$ product of the invA and invE genes ${ }^{16}$ were used. Additionally, a 488bp fragment of the sefA gene, specific for strains of $S$. enterica subsp. enterica serovar Enteritidis ${ }^{17,18}$, was also amplified. Finally, the same samples were used to amplify a $620 \mathrm{bp}$ fragment of the $f l i C$ (flageline) gene, with sequences specific to $S$. enterica subsp. enterica serovar Typhimurium strains ${ }^{17}$. For PCR amplification, a final volume of $25 \mu \mathrm{L}$ containing $1.5 \mathrm{mM}$ $\mathrm{MgCl}_{2}, 100 \mu \mathrm{M}$ deoxyribonucleoside triphosphate, $0.2 \mu \mathrm{M}$ of each oligonucleotide, and $1 \mathrm{U}$ of Taq $\mathrm{ADN}$ polymerase was used. The amplification was done as follows: an initial denaturation at $94^{\circ} \mathrm{C}$ (5min) was followed by 30 cycles of denaturation at $94^{\circ} \mathrm{C}(30 \mathrm{~s})$, annealings at $55^{\circ} \mathrm{C}(1 \mathrm{~min})$, extensions at $72^{\circ} \mathrm{C}(1 \mathrm{~min})$, and finally, an extension at $72^{\circ} \mathrm{C}(10 \mathrm{~min})$. The amplified products were visualized electrophoretically on $2 \%$ agarose gel ${ }^{16,17}$. For quality control, we used S. enterica subsp. enterica serovar Typhi CDC11 (CVCM 495), S. enterica subsp. enterica serovar Enteritidis CDC57 (CVCM 497), S. enterica subsp. enterica serovar Typhimurium CDC64 (CVCM 489), Shigella flexneri ATCC29903 (CVCM 634), and E. coli ATCC25922 $(\mathrm{CVCM} 765)^{19}$.

\section{Ethical considerations}

Informed consent was sought from the parents or representatives of underage patients, allowing the latter to participate in the investigation. A questionnaire was used to collect epidemiological data following the principles proposed by the model ethical protocol for the collection of samples and in accordance with the Declaration of Helsinki ${ }^{20}$. Each patient was assigned a code, which was used to identify him or her throughout the investigation, in order to maintain confidentiality.

\section{RESULTS}

An elevated frequency of positive coprocultures was found throughout the age range and in both sexes for the 330 individuals with ADS who attended state clinics in Cumaná (Table 1). Nevertheless, the highest (39.4\%) frequency of ADS sufferers was found in children between 0 and 2 years old.

Overall, 14 (4.2\%) strains of Salmonella sp. were identified (Table 2), distributed equally between the sexes and from the following age groups: 0-2 years $(n=3), 3-4$ years $(n=4), 5-6$ years $(n=1)$, and 
TABLE 1 - Frequency of individuals with acute diarrheic syndrome and positive coprocultures by age group from different state clinics in Cumaná, State of Sucre, Venezuela.

\begin{tabular}{lrrrrr}
\hline & \multicolumn{2}{c}{ Individuals with ADS } & & \multicolumn{2}{c}{ Positive coprocultures } \\
\cline { 2 - 3 } \cline { 6 - 7 } Age (years) & $\mathbf{n}$ & $\mathbf{\%}$ & & $\mathbf{n}$ & $\%$ \\
\hline $0-2$ & 130 & 39.4 & & 100 & 76.9 \\
$3-4$ & 50 & 15.2 & & 38 & 76.0 \\
$5-6$ & 34 & 10.3 & & 27 & 79.4 \\
$7-8$ & 29 & 8.8 & & 21 & 72.4 \\
$9-10$ & 68 & 20.6 & & 52 & 76.5 \\
$>10$ & 19 & 5.8 & & 14 & 73.7 \\
\hline Total & $\mathbf{3 3 0}$ & $\mathbf{1 0 0 . 0}$ & & $\mathbf{2 5 2}$ & $\mathbf{7 6 . 4}$ \\
\hline
\end{tabular}

ADS: acute diarrheic syndrome. Positive coproculture: individuals with ADS showing an abundance of bacteria on microscopic analysis of the feces and pure cultures of a bacterial strain.

TABLE 2 - Frequency of enterobacteria isolated from positive coprocultures from individuals with acute diarrheic syndrome from different state clinics in Cumaná, State of Sucre, Venezuela.

\begin{tabular}{lcc}
\hline & \multicolumn{2}{c}{ Individuals with ADS } \\
\cline { 2 - 3 } Isolated bacteria & $\mathbf{n}$ & $\mathbf{\%}$ \\
\hline Escherichia coli & 85 & 25.8 \\
Proteus sp. & 27 & 8.2 \\
Shigella sp. & 16 & 4.8 \\
Salmonella sp. & 14 & 4.2 \\
Klebsiella sp. & 24 & 7.3 \\
Citrobacter sp. & 25 & 7.6 \\
Other enterobacteria* & 28 & 8.5 \\
\hline Total & $\mathbf{2 1 9}$ & $\mathbf{6 6 . 4}$ \\
\hline
\end{tabular}

ADS: acute diarrheic syndrome. *others: Escherichia sp., Enterobacter sp., Pantoea sp., Morganella sp., Providencia sp., Yersinia sp., and Serratia sp.

9-10 years $(\mathrm{n}=6)$. The highest frequencies of other enterobacteria species were: Escherichia coli (25.8\%), followed by Proteus sp. (8.2\%), Citrobacter sp. (7.6\%), and Klebsiella sp. (7.3\%). Furthermore, 33 strains of bacteria species from families other than Enterobacteriaceae were isolated from positive coprocultures.

Amplification of the invA/invE gene produced characteristic products in the 14 strains identified as belonging to the Salmonella genus, isolated from fecal samples from individuals with ADS and purified from isolates grown in BHI (Figure 1A). Of these, 7 Salmonella enterica subsp. enterica serotype Enteritidis strains and 4 of the Typhimurium serotype strains (Figures 1B and C) were identified by the amplification of the sefA and fliC fragments, respectively; 3 Salmonella strains belonging to other serotypes that did not amplify these genes were also identified.

We observed that the strain isolated from sample 240 amplified three gene fragments: the $620 \mathrm{bp}$ fragment, specific to the Enteritidis serotype, and two other larger fragments. In contrast, the PCR done with the samples obtained from the control group, as well as with 46 fecal samples from individuals with negative coprocultures and $30 \mathrm{fecal}$ samples in which other bacterial species were isolated, did not amplify any of the fragments expected for strains belonging to the Salmonella genus.

In addition, we were able to amplify the $457 \mathrm{bp}$ fragment specific to Salmonella species, amplified from DNA isolated from selenite broth inoculated directly with the 14 fecal samples from which the Salmonella strains were isolated. On the other hand, we were not

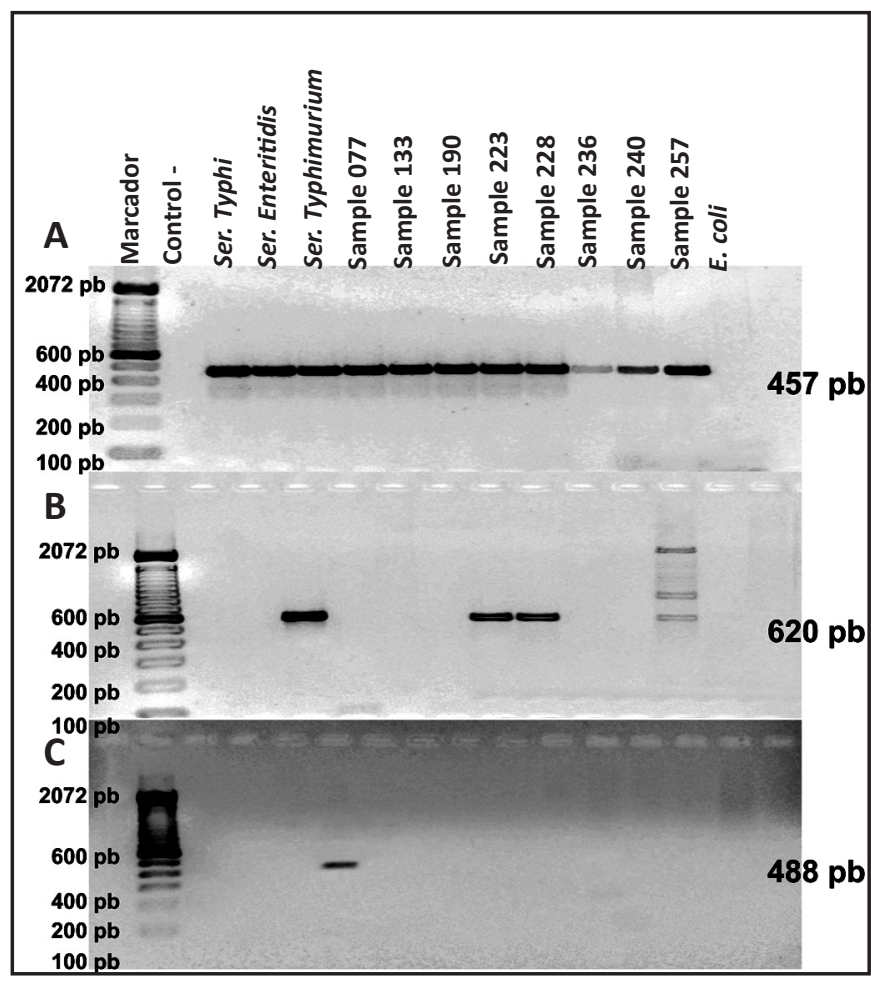

FIGURE 1 - Polymerase chain reaction amplification of the invA/E (A), sefA (B), and fliC (C) genes from control strains and analyzed samples. Water and Escherichia coli (CVCM765) were used as negative controls, Salmonella typhi (CVCM495), Salmonella enteritidis (CVCM497), and Salmonella typhimurium (CVCM489) were used as positive controls. Molecular weight marker 100pb (Invitrogen). Samples: strains isolated from fecal samples from individuals with acute diarrheic syndrome in the City of Cumaná, State of Sucre, Venezuela.

able to amplify DNA isolated from selenite broth inoculated with the 30 fecal samples from which other enterobacteria species had been isolated, or from 10 negative coproculture feces.

\section{DIscussion}

Similar high prevalences of positive coprocultures in individuals suffering from ADS were reported by the Pan American Health Organization (PHO) in 2002 and in investigations undertaken by Urbina and Pequenese ${ }^{21}$, who indicated that diarrheic syndrome is among the principal causes of infant morbidity and mortality in Venezuela, mainly affecting children from families that live in marginal zones with deficient sanitary and nutritional conditions. Furthermore, Gil et al. ${ }^{22}$, after examining 39.697 coprocultures, reported that Salmonella was the bacteria with the highest incidence in children less than one year old. Similarly, Ogunsanya et al. ${ }^{23}$ registered an infection rate of $59.1 \%$ for 315 diarrheic fecal samples from children under five years old, with bacteria as the only causal agents. Notario et al. ${ }^{24}$ reported that $49.9 \%$ of cases of enteropathogenic microorganisms in children with acute diarrhea were positive for bacteria. These results, together with those of this study, indicate a high frequency of bacterial infections in children with diarrhea.

Our finding that the highest frequency of bacterial infections in individuals with $\mathrm{ADS}$ occurs in children coincides with that reported by Viscaya et al. ${ }^{25}$, who evaluated 613 fecal samples in individuals with ADS caused by bacteria in the city of Mérida and found the highest frequency of infection in children under two years old. The frequency of bacterial infections in Ciudad Bolívar was also most 
frequent in children under two, based on a study done with 110 children between 0 and 5 years old ${ }^{26}$. Rincón et al. ${ }^{1}$, however, after analyzing 366 fresh fecal samples from children under five years old with acute diarrhea due to enteropathogenic bacteria, found that only $13.4 \%$ tested positive, a percentage much lower than that found in this study.

The high frequency of $E$. coli found in this study was to be expected; this species is a saprophytic bacterium that normally inhabits the intestine and only causes diarrhea in the presence of virulence factors that can lead to invasion of the gastrointestinal tissue and produce toxins with enterotoxic effects, among others. Orlandi et al. ${ }^{27}$ examined 470 children under 6 years old in Porto Velho, Brazil, in order to ascertain the etiology of diarrheic infections and reported that the most prevalent bacterium was E. coli (18.2\%).

Salmonellosis can affect individuals at any age but shows a higher incidence in breast-feeding babies and young children ${ }^{28}$. Rincón et al. ${ }^{1}$ found frequencies of $3.3 \%(n=12)$ for Shigella and $1.9 \%(n=7)$ for Salmonella, significantly less than those found in Cumaná in this study. Viscaya et al. ${ }^{25}$ reported a Shigella infection rate of $42.9 \%$ in Mérida. Albarado et al. ${ }^{29}$ registered frequencies of $10 \%$ for Salmonella and $16 \%$ for Shigella in a total of 96 fecal samples taken from children under six years old with acute diarrheic syndrome in Cumaná. The prevalences of Salmonella and Shigella in children under five in our study ( 3.9 and $2.8 \%$, respectively) were much lower than those found by Albarado et al. ${ }^{29}$. This could be due to the fact that these microorganisms are normally associated with epidemics, which can cause large variations in their frequencies in individuals with $\mathrm{ADS}^{30}$.

Villalobos and Torres ${ }^{31}$ applied a combination of PCR and hybridization for the detection of the virA gene in virulent Shigella spp. and enteroinvasive E. coli (EIEC) strains, showing the high sensitivity and specificity of these methods both in pure culture strains and in samples of commercial mayonnaise contaminated with S. dysenteriae. PCR has also proven to be a quick, highly sensitive, and specific technique for the detection of Shigella in feces ${ }^{32}$ and food ${ }^{31,33}$ using different protocols. These protocols use primers with sequences localized in Shigella and EIEC invasion plasmids, ${ }^{34}$ as well as other plasmids or chromosomal sequences ${ }^{35}$.

As regards the molecular diagnosis of Salmonella, protocols of multiplex PCR have been standardized with the same genes as those used in this and other studies for the identification of all of the serotypes of this genus. Multiplex PCR has also been used for the identification of Salmonella Typhimurium and Enteritidis in environmental swabs and samples taken from chicken farms, thus demonstrating the scope of the PCR technique in epidemiological studies $^{36}$. Oliveira et al. ${ }^{18}$ used PCR for the detection of strains of Salmonella sp. as well as for the identification of Salmonella Enteritidis, Salmonella Gallinarum, Salmonella Pullorum, and Salmonella Typhimurium in samples taken from chickens collected in the field. These authors reported a specificity of $100 \%$ for the detection of Salmonella using oligonucleotides that amplify the invA gene. However, when the oligonucleotides that amplify the fliC gene (Salmonella Typhimurium) and the sefA gene (Salmonella Enteritidis, Gallinarum, and Pullorum) were applied, they found that the detection levels varied depending on the number of cells used per species. Nevertheless, PCR detected more positives in the samples analyzed than did the microbiological technique used.

The results of this investigation agree with Oliveira et al. ${ }^{18}$ in that the amplification of the invA region for detecting Salmonella sp. did not generate either nonspecific amplifications or cross-reactions when amplified in other species of enterobacteria isolated from patients with acute diarrheic syndrome, thus demonstrating its high specificity.

Infections due to Salmonella and Shigella are conventionally diagnosed by the isolation and identification of the microorganism from cultures of the fecal material. Nevertheless, although this method is precise, it takes time to apply and does not permit identification of the salmonellosis serovars. Hence, this study, like many others, shows that PCR offers an alternative or complementary technique permitting the identification of Salmonella species using different extraction protocols and PCR modes, thus providing a faster and more reliable diagnosis of the microorganism producing the clinical condition. Here, we analyze a method that can potentially be used as a diagnostic protocol that produces results very rapidly; when fecal samples are used after incubation in selenite broth for $8 \mathrm{~h}$, identification can be made within $12 \mathrm{~h}$ of reception. In addition, molecular characterization helps us to understand the true nature of the epidemiology of infections caused by the different Salmonella serotypes. This not only makes their identification easier but also helps to determine the pathogenic potential (virulence genes) of the isolated strain.

\section{ACKNOWLEDGMENTS}

We would like to acknowledge the cooperation of the health personnel of the Salvador Allende, Caigüire; Dr. Ramón Martínez, Las Palomas; Laboratorio Comunitario, Villa Olímpica; and La Llanada and Brasil Health Clinics in Cumana, which allowed us to carry out this study.

\section{CONFLICT OF INTEREST}

The authors declare that there is no conflict of interest.

\section{REFERENCES}

1. Rincón G, Ginestre M, Harris B, Romero S, Martinez A. Frecuencia de bacterias enteropatógenas en niños menores de cinco años. Kasmera 2002; 30:33-41.

2. Ministerio del Poder Popular para la Salud. Boletin Epidemiologico. Semanas epidemiológicas n 54; 2007-2008. [cited 2011 January 20]. Available from: http://www.mpps.gob.ve/

3. Ministerio del Poder Popular para la Salud. Boletin Epidemiologico. Semanas epidemiológicas n 52; 2011. [cited 2012 january 20]. Available from: http://www.mpps.gob.ve/

4. Van Loock F, Ducoffre G, Dumont JM, Libotte-Chasseur ML, Imberechts H, Gouffaux M, et al. Analysis of foodborne disease in Belgium in 1997. Acta Clin Belg 2000; 55:300-306

5. Gillespie I, O’Brien S, Adak G, Ward L, Smith H. Foodborne general outbreaks of Salmonella enteritidis phage type 4 infection, England and Wales, 1992-2002: where are the risks? Epidemiol Infect 2005; 133:795-801.

6. Shu-Xuan D, An-Chun C, Ming-Shu W, Ping C. Gastrointestinal tract distribution of Salmonella enteritidis in orally infected mice with a species-specific fluorescent quantitative polymerase chain reaction. World J Gastroenterol 2007; 13:6568-6574.

7. Reed K, Meece J, Henkel J, Shukla S. Birds, migration and emerging zoonoses: West Nile Virus, Lyme Disease, Influenza A and Enteropathogens. Clin Med Res 2003; 1:5-12.

8. Doyle M, Erickson C. Reducing the carriage of foodborne pathogens in livestock and poultry. Poultry Sci 2006; 85:960-973. 
9. Urrestarazu M, Liprandi F, Pérez E, Gonzalez R, Schael I. Características etiológicas, clínicas y sociodemográficas de la diarrea aguda en Venezuela. Rev Panam Salud Publica 1999; 6:149-153.

10. Servicio Autónomo Hospital Universitario de Maracaibo-Ministerio de Salud (SAHUM-MS). Boletin sobre etiología y resistencia bacteriana. $6^{\text {th }}$ edtion. Maracaibo, Venezuela: SAHUM-MS; 2005.

11. Wang Q, Kong F, Jelfs P, Gilbert GL. Extended phage locus typing of Salmonella enterica serovars typhimurium, using multiplex PCR-based reverse line blot hybridization. J Med Microbiol 2008; 57:827-838.

12. Fang Q, Brockmann S, Botzenhart K. Improved detection of Salmonella sp. in foods by fluorescent in situ hybridization with $23 \mathrm{~S}$ rRNA probes: a comparison with conventional cultural methods. J Food Prot 2003; 66:723-731.

13. Vieira-Pinto M, Oliveira M, Bernardo F. Evaluation of fluorescent in situ hybridization (FISH) as a rapid screening method for detection of Salmonella in tonsils of slaughtered pigs for consumption: a comparison with conventional culture method. J Food Saf 2005; 25:109-119.

14. Winn W, Allen S, Janda W, Koneman E, Procop G, Schreckenberger P, et al. Koneman's Color Atlas and Textbook of Diagnostic Microbiology. $6^{\text {th }}$ edition. New York, USA: Lippincott Williams \& Wilkins; 2005.

15. MacFaddin J. Biochemical Tests for Identification of Medical Bacteria. $3^{\text {rd }}$ edition. New York, USA: Lippincott Williams \& Wilkins; 2000.

16. Stone G, Oberst R, Hays M, Macvey S, Chengappa M. Deteccion of Salmonell serovars from clinical samples by enrichment broth cultivation-PCR procedure. J Clin Microbiol 1994; 37:1742-1749.

17. Oliveira S, Santos L, Schuch D, Silva A, Sallr S, Canal C. Detection and identification of Salmonella from poultry-related samples by PCR. Vet Microbiol 2002; 87:25-35.

18. Edwards R, Spchifferli D, Maloy S. A role for Salmonella fimbriae in intra peritoneal infections. Am J Trop Med Hyg 2000; 97:1258-1262.

19. Centro Venezolano de Colecciones Microbiológicas (CVCM). Catálogo del Centro Venezolano de Colecciones Microbiológicas. Caracas, Venezuela: Instituto de Biología Experimental. Facultad de Ciencias. Universidad Central de Venezuela; 2000.

20. Council for International Organizations of Medical Sciences (CIOMS) International Ethical Guidelines for Biomedical Research Involving Human Subjects. Genebra, Switzerland: CIOMS; 2002.

21. Urbina G, Pequenese M. Agentes bacterianos de diarrea aguda. Manual de laboratorio. Caracas, Venezuela: Fuvesi. Insalud; 1999.

22. Gil A, Mazón A, Martin C, Urtiaga M, Inza E. Salmonelosis no tifoidea en un área de salud de Navarra, España. Rev Esp Salud Publica 2002; 76:49-56.
23. Ogunsanya P, Otimi V, Adenuga A. A study of the etiological agents of chilhood diarrhoea in Lagos, Nigeria. J Med Microbiol 1994; 40:10-14.

24. Notario R, Morales E, Carmelengo N, Binsztein N, Depretis A, Gambante T. Microorganismos enteropatógenos en niños con diarrea aguda en dos hospitales de Rosario, Argentina. Medicina 1993; 53:289-299.

25. Viscaya LE, Flores A, Hernandez J.G, Nieves B, Perez I. Origen bacteriano de la enfermedad diarreica aguda en Mérida. Venezuela. Rev Cub Med Trop 1999; 51:14-19.

26. Cermeño J, Hernández I, Camaripano M, Medina N, Guevara A, Hernández C. Etiología de diarrea aguda en niños menores de 5 años Ciudad Bolívar, Venezuela. Rev Soc Venez Microbiol 2008; 28:55-60.

27. Orlandi P, Magalhaes G, Matos N, Silva T, Penatti M, Nogueira P, et al. Etiology of diarrheal infections in children of Porto Velho (Rondonia, Western Amazon region, Brazil). Braz J Med Biol Res 2006; 39:507-517.

28. Fisher J. Records a resurgence in Salmonella enteritidis infection through the European union. Euro Surveill 1997; 1:24-26.

29. Albarado L, Guzman Y, Guzman M, Betancourt J. Salmonella spp y Shigella spp. Asociados con síndrome diarreico agudo en niños menores de seis años de edad. Kasmera 2005; 33:132-141.

30. Valdespino J, Garcia A, Glono S, Salcedo A, Alvarez R, Sepulveda J. Epidemiologia y etiología de las diarreas infecciosas: el caso de México. Rev Latinoamer Microbiol 1994; 36:307-324.

31. Villalobo E, Torres A. PCR for detection of Shigella spp. in mayonnaise. Applied Environ Microbiol 1998; 64:1242-1245.

32. Jafari F, Shokrzadeh L, Hamidian M, Salmanzadeh A, Zali M. Acute diarrhea due to enteropathogenic bacteria in patients at hospitals in Tehran. Jap J Infect Dis 2008; 61:269-273.

33. Warren BR, Parish ME, Schneider KR. Shigella as a foodborne pathogen and current methods for detection in food. Crit Rev Food Sci Nutr 2006; 46:551-567.

34. Farshad S, Sheikhi R, Japoni A, Basiri E, Alborzi A. Characterization of Shigella strains in Iran by plasmid profile analysis and PCR amplification of ipa genes. J Clin Microbiol 2006; 44:2879-2883.

35. Gomez O, Bai J, Newell E. Detection of Escherichia coli, Salmonella ssp., Shigella ssp., Yersinia enterocolitica, Vibrio cholerae, and campylobacter ssp. Enteropathogens by 3-reaction multiplex polimerase chain reaction. Diagn Microbiol Infect Dis 2008; 63:1-9

36. Kingombe CI, Cerqueira-Campos ML, Farber JM. Molecular strategies for the detection, identification, and differentiation between enteroinvasive Escherichia coli and Shigella spp. J Food Prot 2005; 68:239-245. 